\title{
Translatability problems of Euphemistic Expressions in Najuib Mahfouz's Palace of Desire: A Pragmatic-Stylistic Perspective
}

\author{
Mohammed Al-Badawi \\ Zarqa University, \\ 15, Az-Zarqa, Jordan
}

DOI: https://doi.org/10.36941/ajis-2022-0o3o

\begin{abstract}
This study addresses the question of the problematic translation of Arabic politeness formulas into English in Palace of Desire. The selected translated utterances were critically reviewed using Brown and Levinson's model of politeness (1987), Culpepper's Impoliteness framework, and Grice's Cooperative principle. The study reveals that the translations of politeness formulas may not necessarily jeopardize the translation's overall authenticity, they do however lead to the loss of some of the text's cultural implications, in the sense that the offered translations remove some stylistic and cultural features that the original author intended their work to have.
\end{abstract}

Keywords: Pragmatic equivalence; Politeness; Pragmatic stylistics; Euphemism

\section{Introduction}

In translation studies, Form and Function are two essential aspects that should always be considered to achieve appropriate transference. However, in cross cultural communication, the relationship between form and function is not always steady. This is particularly true when it comes to the area of literary translation because a translator cannot make judgments about the correspondence between form and function in a social vacuum.

Xiujun (2001, p. 11) states that politeness phenomena have recently become central to discussions of social human interaction. Munday (2001, p. 183) argues that the incorporation of translation research with politeness studies offers further potentials for the study of social and ideological aspects of cross cultural communication. For instance, House (1998) tackled the relationship between translation and politeness. However, she was also quite interested in the sociocultural aspects of politeness in language.

Translation is a process that is executed on languages to transfer a text from one language (referred to as the source text) into another language (normally referred to as target text). The transmission is based on the concept of equivalence, which is described by de Waard and Nida (1986) as a collection of forms that will match the original source language text's lexical and grammatical levels of meaning. Weyland (2000: 8) views translation as a subjective operation by its very essence. She assumes that lexis choices made by an interpreter are roughly determined by his/ her predictions and background. She was primarily interested in linguistic behavior while also emphasizing the 
socio-cultural aspects of language etiquette. However, what sounds wrong to one person might be perfectly acceptable to someone else and vice versa.

When it comes to word for word or structure for structure translation, Nida (1964), cited in Weyland (2001), believes that formal equivalence is the most important factor. A dynamic equivalent would be preferable to him, meaning that the text would have the same effect on every receiver. According to Nida (1964), the notion of equivalence must cover both dynamic and formal equivalence to achieve satisfactory translation. Yet there are cultural aspects in the source language text (SLT) that are said differently in the target language text (TLT) and these things form a cultural difference gap. This is one of the most difficult tasks for translators when they are engaged in translation, especially in the case of literary text translation.

Thus, translating a literary piece differs from, say, translating an academic or legal text. The main distinction between the two types of texts is the goal for which they were written in the first place. When producing a scientific or legal book, the writer's goal is to provide information to the reader, among other things, whereas the writer of a literary work has a different goal. It is usually believed that a writer's primary goal while creating a literary composition is to entertain and amuse the audience. Writers, translators, and readers will not be able to achieve the first goal unless they have a thorough understanding of the culture, social values, and customs of the target audience and include them in the text. It is difficult to translate certain characteristics of language into the target text language without taking into account the culture. As a result, the representation would be odd or even offensive to the readers of the target language. This accords with the view of many researchers (e.g., Nida and Reyburn (1981); Smith (1987); Bochner (1982); Hall and Feedle (1975)) who agree that cross-cultural communication involves problems of meaning. Knowing this, a translator's most difficult task when translating a literary text is to transfer those features of the text so that they do not sound or look strange to the target language readers, while keeping in mind that their culture is distinct from that of the original text.

Linguistic politeness in this context refers to the core of many definitions of politeness offered by linguists like Sifianou (1992: 82-83) and Eelen (2001: 30-86). This core refers to "a means of expressing consideration for others." Following this view, Kasper (1990) argues that linguistic politeness is seen as a matter of strategic interaction that tries to reach social goals such as avoiding conflict and maintaining harmonious relations with individuals. In the same manner, linguistic impoliteness would be seen as deliberate verbal interaction that tries to reach social goals such as seeking conflictive relations with individuals in conversation.

The translation of politeness formulas is one aspect that creates a stimulating difficulty when translating culture-bound expressions. Linguists agree that politeness, as a concept of "being socially nice," is universal. But this social niceness takes on a variety of forms depending on one's culture. It is necessary for the translator to have a precise pragmatic understanding or knowledge of the purposes of politeness formulas in the source and target text cultures.

Knowing the relationship between the semantic meaning and pragmatic function of any politeness formula is called pragmatic knowledge in this context. Such a link is occasionally obvious, such as when Arabic thanks term <shukran> is translated to "thank you." On the other hand, the relationship can be difficult at times, such as when the Arabic utterance /nagiiman/ is said to someone after taking a bath or getting a haircut. This is a prayer to God to bring that person health, prosperity, and happiness, because it marks a casual change in that person's state in everyday life.

Few researches on the translation of politeness in literary texts has been done; for instance, Hatim and Mason (1997) investigated politeness in screen translation. They attempted to show how politeness is underrepresented in that field. Their use of politeness in the study conforms with Brown and Levinson's notion of politeness (1987). In their attempt to analyze the data, they used the super strategies in Brown and Levinson's model (1987) which consists of some examples of screen translation of the English subtitled French film Un Coeur en hiver ('A heart in winter'; Clude Sautet, 1992). The study offered some insights into the translation of politeness and concluded that it is almost unavoidable that certain components of meaning must be sacrificed or ignored, and then 
evaluated how this omission may impact the target audience. They also observed that target language auditors had a tough time retrieving interpersonal meaning in its totality. Their study's modest conclusions, they said, need further empirical research in various languages to verify their generalizability.

Euphemisms as politeness strategies in Arabic subtitles of the American sitcom Friends were examined as part of Al- Adwan's (2009) research on euphemisms. His use of politeness draws mainly on the major tenets of Brown and Levinson's model of politeness (1987). The researcher proposed a modified and extended model of euphemization as a strategic output of politeness that is basically built upon the other two models of euphemization by Williams (1975) and Warren (1992). According to his data analysis, Arabic subtitlers in Friends utilize several forms of euphemism from the suggested paradigm to manage allusions to sex, religion, and death. The study also demonstrates that euphemism as a politeness tactic in Arabic subtitles has a significant effect in developing an accepted type of interaction for Arab viewers.

In another study, House (1998) sets out to explore the relationship between politeness and translation with specific reference to German-English translation. The researcher starts with highlighting the different views on politeness. According to Watts et al. (1992), "Thinking of politeness as a set of societally taught behavioral patterns allows us to investigate the wider social objectives of politeness, such as in the educational system, prescriptive grammar, and translation procedures" (House 1998: 55). Brown and Levinson's concept for the face-saving characteristic of politeness, she says, cannot readily be adopted in translation. Other researchers, such as Al-Adwan (2009), Zitawi (2004), Hatim and Mason (1997), and Hickey (2001), as well as this study, have used Brown and Levinson's Model of Politeness on translation studies and revealed that it is useful in their data analysis because these studies conform to the face-management view of politeness. According to Zitawi (2004), civility is an essential component in judging translation. In her sample she found some aspects in English text rendered differently in German, i.e., interlocutors usually were more direct than found in English, where she reports that:

the translation retains the ideational functional component but substantially changes the interpersonal one because the devices used to mark the original interpersonally are not rendered equivalently in German (House 1998:69)

Hickey (2001) also examines how 'positive politeness readers (Spaniards)' respond to literal translations of English texts which are basically negative politeness oriented. In his small scale experiment, he has taken six excerpts that involve negative politeness forms from the English novel Therapy by David Lodge. He presented those excerpts to a focus group of university students who were native speakers of English and gave them the task in English to discuss the person and the type of behaviour involved in each excerpt. At another level, he provided a focus group of Spanish university students the appropriate Spanish translation of the novel (Terapia) translated by Fransco Roca (1995) and assigned them the identical job as described above in Spanish. At a third level the same excerpts were given to a control group of bilinguals of English and Spanish or near bilinguals having proficiency and fluency in both languages. The group were given the same task but with freedom to answer with whichever language they chose. The study concludes that some literal translations of negative politeness markers were not recognized by Spanish readers. Hickey goes on to explain that Spanish speakers could not recognize the negative politeness probably because this form does not exist in their categories and classifications of politeness pre-existing in their minds. (Hickey 2001: 238)

Since politeness translation can take on many forms in different languages, Akbari (2014, pp.1193-120o) proposes a "Perks of Politeness Translation Strategies" framework for translating polite expressions in order to determine the workability, feasibility, and practicality of polite items in the target language. The proposed category is entirely cross-cultural and is likely to be used in any culture. Akbari uses Brown and Levinson's (1987) model of politeness and Juliane House's (1997) 
model of translation quality evaluation to provide solid support for the desired framework. The former is concerned with role or pragmatic linguistics, whereas the latter is concerned with translation quality or functional translation.

The purpose of this study is to explain why polite expressions are chosen in the target language using the intended framework in practical or pragmatic translation. The rationale for using this framework for this study is to combine and conglomerate the core of politeness principles in linguistics and politeness translation in pragmatic translation studies. This framework provides a perspective to become acquainted with the similarities and variations between polite phrases across languages and cultures. As a result, putting the current framework into practice, subtitling, and dubbing translation pave the way for attracting and absorbing a larger audience in this regard. Therefore, in order to fulfill both the demands of the translator and the target audience, Akbari (2014) divides politeness translation into two broad categories known as solidarity and deference strategies. There are five steps in the Solidarity Strategy: "attract the reader's attention," "magnify," "eschew dispreferred structure," "act favorably," and "be vague." However, deference strategies are "indirect rendering", "reciprocal assumption" as well as "rapprochement."

\section{Method}

In this study, 10 examples of translated Arabic politeness formulas in Najuib Mahfouz's Palace of Desire, translated by Hutchins and Roberts, will be investigated. The selection of the examples is based on the relevance of these utterances to the social and religious aspect of politeness formulas in Arabic. Politeness in Arabic is influenced by both the Arab and Islamic culture, thus politeness utterances are loaded with religious words. Another reason for the selection of the examples is based on the researcher's sense of his first language - Arabic, and his knowledge of English, i.e. wherever he felt there are possible cases of loss in meaning in politeness in the presented translation. It is worth mentioning that the translated formulas refer to Arabic politeness in general and Egyptian politeness in particular since the writer of the Arabic text is Egyptian. The selected examples cannot be claimed to be representative of the whole problem facing English-Arabic translators but they can shed light on the problem and serve as a small contribution to the study of the problem, hoping to help researchers and translators to better understand and handle this problematic area.

This study is analytical in nature, so it will critically review the translation of the lexis that involve politeness formulas in the related texts in an attempt to point out the differences in the realization of politeness in English and Arabic. It should be obvious that it is not the intention of this researcher to make judgements about the appropriateness and the accuracies of the presented translations. However, the researcher will comment on the discrepancies in the presentations of meaning related to linguistic politeness to the best of his knowledge.

The examples below of the selected politeness formulas will be commented on the pragmatic, social, and religious levels. A little context has been given in each example, however, what is of interest are the expressions in bold. Examples will be looked at in light of the pragmatic transfer of Arabic pragmatic function of norms and forms of performing speech acts into English that have resulted in pragmatic inappropriateness on the level of linguistic politeness between English and Arabic.

\section{Discussion and Results}

\section{Example 1}

Without raising her head from her work, Amina murmured, "We've got to make sure the food's delicious."

Umm Hanafi smiled, gestured toward her mistress with her chin, and said, "Your skill will take care of that". She planted her hands in the bowl once more to resume punching the dough. 
"I wish we had contented ourselves with distributing stew to the needy around al-Husayn Mosque." (Hutchins et al. 1997: 27)

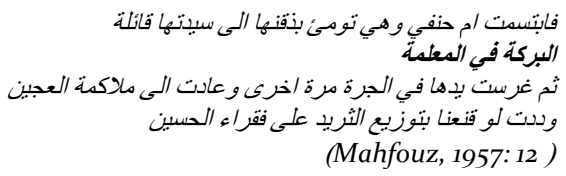

The expression <?ilbarakah fii ?ilmigalimah> which literally means "blessings are in the Mistress," has been rendered as "your skill will take care of that". This is an example of how speakers of Arabic are positive politeness oriented. The utterance has two aspects of positive politeness. The first is the use of the word <?ilmigalimah>, which means "the mistress," a term of address usually used by a subordinate addressing someone of a higher status - often found when an employee addresses a female employer. This term of address is used to show in-group membership as appreciation towards the speaker's positive face. We notice that this aspect is not rendered in the English translation. The second aspect refers to the religious word <?ilbarakah> meaning "the blessings" which also refers to the competence of the addressee in certain regards. This is also a positive politeness strategy of attending to the speakers' face. In the translation "your skill will take care of that" the translator maintained the positive politeness strategy of attending to the hearer's positive face. Yet native speakers of English would not use such a formula, opting for something more along the lines of, "I am sure you can do it."

Example 2

With a gleam in his protruding eyes, Ibrahim tilted his head to the left to gaze down at his wife. Then, sighing victoriously, he said, "A witness from her own family has testified. God bless you, mother-inlaw"

(Hutchins et al. 1997: 27)

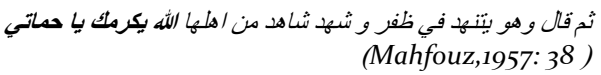

The Arabic expression <?alah yikrimik yaa hamaatii > which literally translates into, "May Allah reward you, my mother in law," is a positive politeness strategy where the speaker makes an invocation to his mother in law to appreciate her positive face. The word, /hamaatii/ which means, "my mother in law" is a term of address used in Egyptian Arabic in particular to show deference towards the hearer. In rendering this polite utterance, it can be noticed that the positive politeness is maintained in the expression, "God bless you, mother in law." Yet, the "mother in law" here fails to reflect as a polite form of address. In addition, the translation of /alah yikrimik/ as "God bless you" is probably something that a religious person would say in English.

Example 3

Then the younger woman had screamed, "I know why you're furious with me. I've known ever since I refused to let you push me around in my own home."

The mother-in-law had shrieked, "My Lord, I testify that al-Sayyid Ahmad Abd al-Jawad is a fine man, but he's fathered a she devil. I deserve to be beaten with a slipper as punishment for picking you."

(Hutchins et al. 1997: 27)

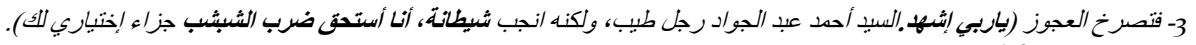

(Mahfouz, 1957: 40)

The expression <yaa rabi ?ish.had ?alsayid ?ahmad gabdeljawaad rajulun tayib walaakinahu ?anjaba shaytaanah>, literally means, "Oh my God, testify that al-Sayyid Ahmad is a good man but he has fathered a demoness." The old woman (Khadija's mother in law) said such an expression as a 
positive politeness strategy towards al-Sayyid Ahmad and as a positive impoliteness strategy towards his daughter, Khadija. The speaker's intention is to make al-Sayyid Ahmad indignant of his daughter, as the old woman is complaining to him about Khadija's bad behaviour with her. This is evident in the self-admonishing utterance "deserves to be beaten with a slipper for choosing you to be my son's wife." As far as the translation is concerned, "My Lord, I testify that al-Sayyid Ahmad Abdeljawad is a fine man, but he has fathered a she-devil" we can observe that "I testify" is not the same as <?ish.had> as the speaker is making a religious plea to God in order to show that she is weak, and lead Ahmad to sympathize with her and support her. Such utterances in the source language, <shaytaanah>, (demoness) and <?anaa ?astahiq darb ishibshib>, (I deserve to be beaten with slippers) to show humiliation are remote in the target language. Thus, the effect of politeness and impoliteness would be ambiguous to readers in the target language.

Example 4

"The fact is, Papa, that these disciplines have won the highest respect in advanced nations. The Europeans cherish them and erect statues in honour of persons who excel in them."

al-Sayyid Ahmad turned his face away, clearly implying: "O God, have mercy". But he was not actually angry.

(Hutchins et al. 1997: 35)

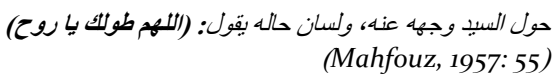

The Arabic expression <?alaahuma tawilik yaa roh $>$ which literally means, "O God, lengthen the soul" is understood by listeners or readers in the source language to refer to the speaker's indignation of the hearer. The speaker is trying to make an invocation to God to grant him patience and strength so that he can become more tolerant and gain self control in a situation of anger. It can also indicate condescension on the part of the speaker in situations such as the above where the speaker implies he is putting up with the hearer's nonsense. This is a positive impoliteness strategy where the speaker snubs the hearer. In the translation of this utterance we can assume that such a pragmatic function is not conveyed to the target language readers by the expression, "O God have mercy."

Example 5

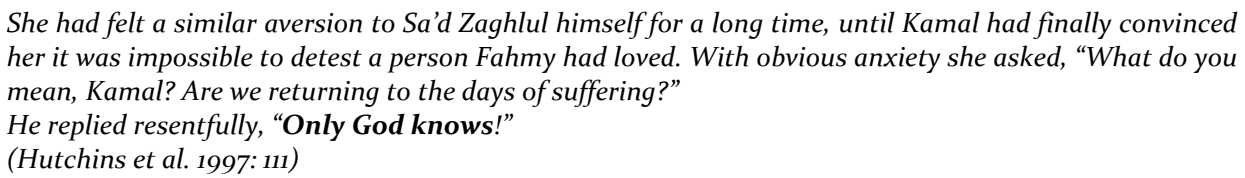
(Mahfouz, 1957: 171)

In this example, the expression <laa yaglamu ilghayba ?ilaa ?alah> which means, "No one but Allah can tell the unseen" is translated by Hutchins into "Only God knows!" There is an element of meaning loss in the source language text if compared with the target language text. The intended religious connotation of "Only God knows!" is not the same to source language readers as the Arabic version, <laa yaglamu ilghayba ?ilaa ?alah> which involves submission of the speaker to Allah's judgment and belief in what is predestined/fated.

Example 6

Khalil said to his mother critically, "Won't you give our father a chance to catch his breath? There's really no need for a tribunal."

The woman's voice grew louder as she replied, "Why are you here? What's brought all of you? Leave her with us, and the rest of you can go in peace."

Ibrahim said gently, "Think of God." 
(Hutchins et al. 1997: 154)

6- فقال ابر/هيم برقة: وحدي الله..

(Mahfouz, 1957: 240)

The expression in this example, <wahidii ilah> literally means "Say Allah is one." It refers to the tawheed principle in Islam, which is to believe in the oneness of God. However, the expression in this context has another pragmatic function, which is culture bound. When this expression is said to people who are having a heated argument and are angry at each other, the pragmatic function is to urge the listeners to calm down. The connotation is drawn from the peace of mind and calmness that a firm believer usually has. The translation of the expression as, "Think of God" is not only uncommon to say in English, it also fails to give the same cultural connotation as the Arabic expression. Of course, this expression is a positive politeness expression towards the hearer where the speaker tries to avoid disagreement to maintain the harmony of the conversation and to tune out what may lead to disharmony.

Example 7

Although Ibrahim and Khalil were smiling, their father-in-law put on a grave face as he answered, "God protect us, Mother."

"May God guard you, al-Sayyid Ahmad. Yet your daughter is averse to it. She calls me Auntie, although I've asked her repeatedly to say Mother. She retorts, 'Then what will I call the one at Palace Walk?'

(Hutchins et al. 1997: 155)

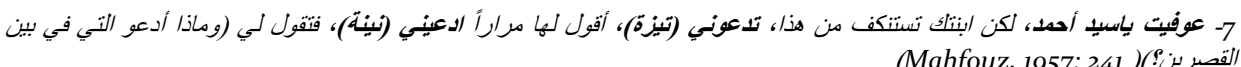

The expression <quufiit yaa sayyid ?ahmad> counts as a positive politeness invocation towards the hearers face; i.e. intensifying interest to hearer. The utterance literally means "may God grant with health Mr. Ahmad.” The pragmatic function in which this utterance is used is to exaggerate interest towards the hearer, so that the old lady can win the hearer's support (al-Sayyid Ahmad). This culture specific meaning is not reflected in the translation "May God guard you!" It is assumed that the source language readers will easily pick up on the intended meaning of <quufiit> but it will create confusion to target language readers as they will not make a connection between the invocation made and the complaint that follows.

Another contrast is the use of the word <tizaa > which is rendered as "Auntie." In general, this word used to be a common social term of address in Egyptian Arabic, said by a wife to her mother in law when a bad or reserved relationship exists between them. So the term is used as a positive impoliteness strategy to attack the hearer's face. At the other end of the line comes <niinah> as another term of address in Egyptian Arabic to indicate a good relationship between a wife and her mother in law or to grand- mothers. An important point to be stressed here is that $<$ niinah $>$ is used only to elderly women in Egypt nowadays. Looking at the renderings of the two terms we can understand that the Auntie and mother will not give the same social connotations maintained by the two terms of address <tiizah> and <niinah> consecutively, and does not reflect on the intended sarcasm or respect conveyed to mothers-in-law.

Example 8

Yasin got up again at once, shaking his head violently, as if to expel his hangover. He went to the sofa and aimed a fierce blow at the back of his wife, who was lying on top of her rival. Maryam screeched and retreated. He pursued her. Blinded by anger, he rained punches on her until she got on the far side of the dining table. Then she took off one of her slippers and hurled it at him, striking him in the chest. He tried to catch her, pursuing her around the hall.

He shouted at her, "I never want to see you again". Then he pronounced the irreversible triple divorce 
formula: "You're divorced, divorced, divorced!"

(Hutchins et al. 1997: 184)

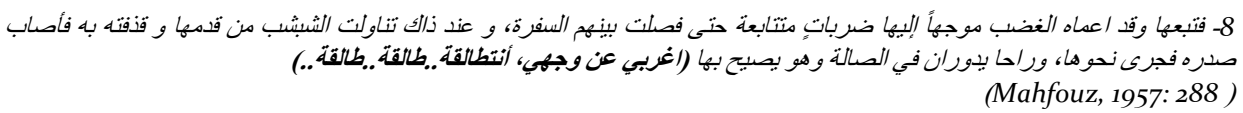

The Arabic expression <?anti taaliqah taaliqah taaliqah> which means, "you are divorced, divorced, divorced" is probably ambiguous and unclear to readers in the target language. The translator added a note preceding the utterance, "then he pronounced the irreversible triple divorce formula" in order to help readers of the target language understand what is meant. In Islamic divorce, if a husband wants to divorce his wife, then he should say a performative speech act, saying the word, $<$ taaliqah $>$. The number of times it is said determines whether he can return to his wife later or not. If this utterance is said three times, (this is a point of debate among scholars of Islam, as they disagree on whether this performative should count as one even if said three times at one occasion, or at three separate occasions, regardless of the number of times it is uttered) then the man cannot be reunited with his wife unless she gets remarried to another man, and then divorced. Only then can her previous husband be allowed to remarry her. This ambiguity in understanding the intended meaning of the utterance can be resolved by adding an explanatory note in an appendix or as a footnote. On the social level, such an act is considered as an extremely dangerous FTA towards the woman, because in conventional Arab patriarchal societies, a divorced woman would be looked down on by society and probably would not have a good chance of re-marrying.

Example 9

She caught his contagious fury and responded sharply, "Not so fast! Don't insult me to my face. I've been very lenient with you until now, but everything has a limit. I'm a person made of flesh and blood. Open your eyes and pray to Fatima's father Muhammad."

He asked in astonishment, "Is this the tone you use to address me?"

"Yes, since that's how you're talking to me."

(Hutchins et al. 1997: 191)

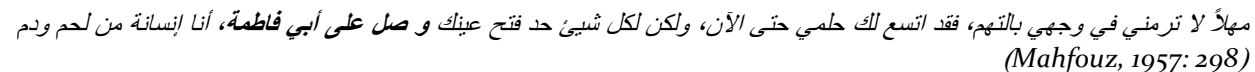

In this example, the Arabic utterance <fattah giinak wa salii galaa ?abii Fatimah $>$ which literally means, "open your eyes and pray to Fatima's father" would be pragmatically unclear to (most) target language readers because it fails to convey the intended pragmatic function. Usually, this expression is used as multi-functions, but basically it is one of the variant forms of praising Prophet Mohammed (peace be upon him) which is used in situations like openings and closing of public places, speeches and books. It might also be used in situations like the above, where the speaker tries to get his angry hearer to calm down by drawing his attention to something else, or to urge an angry person to act rationally. In the translation, "Open your eyes and pray to Fatima's father Muhammad" the translator added the word "Muhammad" to clarify who Fatima's father is. Yet the expression is still confusing to the target language readers because of the ambiguity of the pragmatic function of the utterance even if they were native speakers of English who are Muslim. In such situations, an explanatory note is also advisable to clear any confusion that may be caused to target language readers.

Example 10

"Listen carefully to me. I don't want to be harsh with you, for you're polite and obedient. On this subject, I can only offer you my advice. You should remember that no one who has neglected my advice has prospered". Then after a brief silence he continued: "Yasin's an example for you of what I'm saying, and I once advised your late brother not to throw himself to destruction. Had he lived, he would be a distinguished man today." 
(Hutchins et al. 1997: 223)

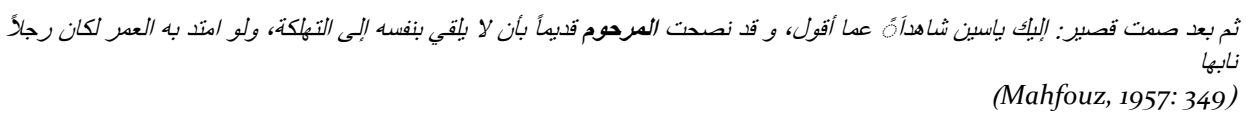

In this example the translation of the word <?almarhuum $>$ has lost meaning when compared with the translated form in English, "late brother." The Arabic word refers to how Arab Muslims speak of the deceased. The utterance of such a word involves the hidden invocation, "May God forgive all his sins and be merciful to him." In addition, the use of such a word is thought of as a polite term of address to refer to a dead person in the presence of their family. In this example we can see how Ahmad addresses Kamal to show respect and appreciation for the deceased. However, the phrase "late brother," literally means, <?alfaqiid> in Arabic, which in turn literally means "the lost one". The use of such an expression in the translation has stripped away the hidden invocation that is intended to reflect the religious politeness and respect, which is part of the Islamic and Arab culture.

\section{Conclusion}

This paper has attempted to shed light on the problematic translation of politeness expressions from Arabic into English. All of the above examples showed loss of translation in one aspect or another when Arabic formulas were rendered into English. The loss is thought of as evidence of the different ways cultures encode their politeness in their language, which reinforces findings of research in politeness that claim the display of politeness is varied across language and cultures. It can also be observed that the Arabic culture's method of encoding politeness is to a certain extent related to Islamic expression that encode a sort of invocation towards the hearer. This invocation is usually meant to be used as a positive politeness strategy where the speaker appreciates the social wants of their hearers in one way or another. The discrepancies in the translation of these politeness formulas can influence the understanding of the message in the target language text and cause confusion to the readers. This is basically because of the pragmatic function of the utterance that is culture bound. A good example of this is:

Ibrahim said gently, "Think of God."

(Hutchins et al. 1997: 154)

6- فقال /بر/هيم برقة: وحدي الله..

(Mahfouz, 1957: 240)

This expression has a pragmatic function as argued in example 9 above that is bound only to Arabic culture where the speaker tries to pacify an angry person or a heated argument between two persons. In order for the reader to understand the translation he/she would have to have a good background of the Arabic culture.

While such representations may not necessarily jeopardize the translation's overall authenticity, they do lead the text to lose some of its cultural implications, removing a feature that the original author intended their work to have. In spite of this, it's important to note that this study is in no way indicative of the entire Arabic literary discourse. At the conclusion of this paper the findings can be said to relate to the specific case studies that have been analysed, but how they fit within a broader framework remains to be seen. Thus, further empirical research is needed in the field of EnglishArabic translation to come out with more comprehensive conclusions in this particular area. 


\section{References}

Al-Adwan, A., (2007). Euphimisation as A Politeness Strategy in Arabic. Ph.D. thesis. Manchester, University of Manchester.

Albassam, A., (2006). Translation into English of the Politeness Strategies in the Speech of Characters in Mahfouz's Narratives. Proceedings of and Conference of the International Association for Translation and Intercultural Studies. University of the Western Cape, South Africa.

Al-Hakim, T. (1973). Fate of a Cockroach; Four Plays of FreedomSelected and Translated from the Arabic by Denys JohnsonDavies. London, Heinemann.

Al-Khatib, M. (2006). The Pragmatics of Invitation Making and Acceptance in Jordanian Society. Journal of Language and Linguistics, 5, 2, pp. 272-294.

Brown, P. and Levinson, S. (1987). Politeness,Some Universals in Language Usage. Cambridge, Cambridge University Press.

de Waard, J \& Nida, E. (1986). From One Language to Another, Functional Equivalence in Bible Translating. Nashville, Thomas Nelson Publishers.

Hatim, B. \& Mason, I. (1990). Discourse and the Translator. London/New York, Longman.

-. (1997). The Translator as Communicator. London/New York, Routledge.

Hickey, L. (2001). Politeness in Translation between English and Spanish. Target, 12,2, pp. 229-240. Cultural Utterances in Literary Discourse from Arabic into English 33

House, J. (1998). Politeness and Translation. In Hickey, L. (ed.), The Pragmatics of Translation. Clevedon, Multilingual Matters, pp. 54-71. Hutchins, W. M., Kenny, L. M. and Kenny, O. (1991).

Najuib Mahfouz Place of Desire, The Cairo Trilogy II. Cairo, The American University in Cairo Press.

Kilpatrick, H. (1999).GhassanKanafani, Men in the Sun \& Other Palestinian Stories. London, Lynne RiennerPublishers.Inc.

Nida, E. A. (1964). Toward a Science of Translating with Special Reference to Principles and Procedures Involved in Bible Translating. Netherlands, Leiden.

-. (1974). The Theory and Practice of Translation. Netherlands, Leiden.

Reyburn, W. D. and Nida, E. A. (1981). Meaning Across Cultures, A Study on Bible Translating.

Maryknoll, Orbis. Watts, R. J. (1989). Relevance and Relational Work, Linguistic Politeness as Politic Behaviour. Multilingua, 8,2-3, pp. 131-166.

Weyland, S. (200o). Translation Models and Model Translations, A Journey across Languages, Time and Culture. Ph.D. thesis. University of Aberdeen.

Zitawi, J. (2004). The Translation of Disney Comics in the Arab World, A Pragmatic Perspective. Ph.D. thesis. Manchester, University of Manchester.

\section{Appendix}

\section{Transliteration System for Arabic Language Symbols of Consonants}

\begin{tabular}{|c|c|c|}
\hline Roman Symbols & Specifications & Arabic Symbols \\
\hline$?$ & Voiceless glottal stop & i \\
\hline $\mathrm{b}$ & Voiced bilabial stop & ب \\
\hline $\mathrm{t}$ & Voiceless alveolar stop & $ت$ \\
\hline th & Voiceless interdental fricative & $\dot{H}$ \\
\hline $\mathrm{j}$ & Voiced alveopalatal affricate & ج \\
\hline$\underline{\mathrm{h}}$ & Voiceless pharyngeal fricative & $\tau$ \\
\hline $\mathrm{kh}$ & Voiceless uvular fricative & $\dot{\tau}$ \\
\hline $\mathrm{d}$ & Voiced alveolar stop & 2 \\
\hline th & Voiced interdental fricative & $\dot{j}$ \\
\hline $\mathrm{r}$ & Voiced alveolar flap & 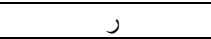 \\
\hline $\mathrm{Z}$ & Voiced alveolar fricative & j \\
\hline $\mathrm{s}$ & Voiceless alveolar fricative & س \\
\hline sh & Voiceless alveopalatal fricative & ش \\
\hline$\underline{\mathrm{s}}$ & Voiceless alveolar emphatic fricative & ص \\
\hline$\underline{\mathrm{d}}$ & Voiced alveolar emphatic stop & ض \\
\hline
\end{tabular}




\begin{tabular}{|c|c|c|}
\hline Roman Symbols & Specifications & Arabic Symbols \\
\hline$\underline{\mathrm{t}}$ & Voiceless alveolar emphatic stop & b \\
\hline$\underline{\mathrm{Z}}$ & Voiced interdental emphatic fricative & ל \\
\hline 9 & Voiced pharyngeal fricative & $\varepsilon$ \\
\hline gh & Voiced uvular fricative & $\dot{\varepsilon}$ \\
\hline $\mathrm{f}$ & Voiceless labio-dental fricative & ف \\
\hline $\mathrm{q}$ & Voiceless uvular stop & ق \\
\hline $\mathrm{k}$ & Voiceless velar stop & ك \\
\hline 1 & Voiced alveolar lateral & J \\
\hline $\mathrm{m}$ & Voiced bilabial nasal & 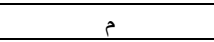 \\
\hline $\mathrm{n}$ & Voiced alveolar nasal & ن \\
\hline $\mathrm{h}$ & Voiceless glottal fricative & . \\
\hline
\end{tabular}

\section{Symbols of Vowels}

\begin{tabular}{|c|c|c|c|}
\hline Roman Symbols & Specifications & Arabic Symbols & \\
\hline $\mathrm{a}$ & Front half-opened unrounded & Fatha & \multirow{4}{*}{ Short Vowels } \\
\hline $\mathrm{u}$ & Back close rounded & Dama & \\
\hline I & Front open spread & Kasra & \\
\hline o & as in duktor (دكتور) in Arabic and "orphan" in English & أو & \\
\hline aа & Front open unrounded & $\mathrm{i}$ & \multirow{3}{*}{ Long Vowels } \\
\hline uu & Back close rounded & أوو & \\
\hline ii & Front close unrounded & إي & \\
\hline $\mathrm{y}$ & Non-syllabic Palatal Approximant & ي & \multirow[t]{2}{*}{ Semi-Vowels } \\
\hline $\mathrm{w}$ & Non-Syllabic Labio-Velar approximant & 9 & \\
\hline ei & as in leih (ليه) in Arabic and "tail" in English & إيه & Diphthong \\
\hline
\end{tabular}

